Konservasi Hayati, 17 (1): 44-48, April (2021)

https://ejournal.unib.ac.id/index.php/hayati/

p-ISSN: 0216-9487

email:konservasihayati@unib.ac.id

e-ISSN: $2722-1113$

\title{
KERAGAMAN GENETIKA BADAK SUMATERA DALAM UPAYA MENDUKUNG KONSERVASI DI INDONESIA
}

\author{
Handayani $^{1 *}$, Dedy Duryadi ${ }^{2}$, Hadi Alikodra ${ }^{2}$ \\ ${ }^{1}$ Jurusan Biologi Fakultas Sains dan Teknologi Universitas Islam As-Syafi'iyah Jakarta \\ ${ }^{2}$ Institut Pertanian Bogor \\ *corresponding author : handayani.saintek@gmail.com
}

\begin{abstract}
The Sumatran rhino is one of the wild animals whose numbers are decreasing in nature. Therefore, the detection of genetic diversity is an important step that must be taken in order to avoid extinction, and conservation efforts are needed for these animals in nature. The sample collection was obtained from rhino captivity in TNWKS Lampung. The sample consisted of (a male named Torgamba and a male named Andalas and Bina and Rosa). The blood collection was assisted by a veterinarian in charge of the health and reproduction of the Sumatran Rhinoceros at SRS. The PCR process used a primer pair (RHCOIF \& RHCOIR). The analysis results showed that the nucleotide bases differed in the four of rhino samples, which were around 95-100 bases, and in the African rhino around 93-101 bases. The results of this study indicate that the Sumatran Rhino Dicerorhinus sumatrensis has variations.
\end{abstract}

Keywords : the Sumateran rhino, COI gene, genetic diversity,conservation

\begin{abstract}
ABSTRAK
Badak Sumatera merupakan salah satu satwa liar yang jumlahnya semakin menurun di alam. Oleh karena itu, deteksi keanekaragaman genetika adalah langkah penting yang harus dilakukan agar dapat terhindar dari kepunahan, serta diperlukan usaha konservasi terhadap satwa tersebut di alam. Koleksi sample didapatkan dari penangkaran badak di TNWKS Lampung. Sample terdiri atas (jantan bernama Torgamba dan jantan bernama Andalas serta Bina dan Rosa). Dalam pengambilan darah dibantu oleh dokter hewan yang bertugas dalam bidang kesehatan dan reproduksi Badak Sumatera di SRS. Proses PCR menggunakan pasangan primer (RHCOIF \& RHCOIR). Hasil analisa terlihat basa nukleotida berbeda pada empat sampel badak yaitu sekitar 95-100 basa, dan pada badak afrika sekitar 93-101 basa. Hasil penelitian ini menunjukkan bahwa Badak Sumatera Dicerorhinus sumatrensis terjadi variasi.
\end{abstract}

Kata Kunci: Badak Sumatera, gen CO1, keragaman genetika, konservasi

\section{PENDAHULUAN}

Indonesia disebut Megabiodiversity Country karena memiliki biodiversity yang sangat besar. Diantaranya terdapat di pulau Sumatera yang menjadi salah satu gambaran kekayaan di Indonesia. Lekagul \& McNelly 
(1977) mengungkapkan diketahui bahwa di dunia ada lima jenis badak diantaranya badak India, badak Jawa, Badak Sumatera yang berada di Asia, serta badak Afrika yang terdapat di Afrika.

Jumlah populasi Badak Sumatera terlihat saat ini mengalami penurunan yang sangat besar sehingga sebarannya pun hanya terdapat pada beberapa daerah diantaranya di Aceh, Jambi, Bengkulu, Lampung. Saat ini keberadaan hidup Badak Sumatera mengalami ancaman yang serius sehingga perlu usaha konservasi. Penurunan jumlah Badak Sumatera di alam dapat terjadi karena perburuan liar, fragmentasi habitat serta konversi habitat. Alikodra (2002) mengungkapkan bahwa keberadaan satwa liar di alam dapat berkembang secara stabil ataupun satwa liar di alam dapat menurun dengan dapatnya satwa menyesuaikan diri dengan lingkungannya. Selain itu ancaman bagi Badak Sumatera karena cara hidup badak yang soliter dan perburuan, serta reproduksi yang sulit dan lambat dan menghasilkan anak keturunan yang terbatas.

Berdasarkan Frankham et al., (2002), hewan dalam jumlah yang sedikit atau rendah maka akan lebih rentan pada sejumlah efek genetik yang merugikan, diantaranya: (a) adanya efek inbreeding maka keragaman genetik akan terjadi penurunan (b) adanya allel yang monomorf pada satwa (c) tidak dapat beradaptasi pada lingkungan. Selain itu, faktor lain penyebab berkurangnya populasi, adalah (i) disebabkan adanya habitat yang terfragmentasi sehingga mendorong aliran gen (gen flow) menjadi terputus, (ii) genetic drift meningkat, dan (iii) inbreeding (kawin silang dalam populasi) antar populasi.

Untuk mendapatkan variasi genetik yang tinggi dalam suatu kehidupan satwa di alam diperlukan usaha konservasi terhadap satwa tersebut di alam khususnya Badak Sumatera yang jumlahnya semakin menurun di alam. Oleh karena itu, deteksi keanekaragaman genetika Badak Sumatera salah satu langkah penting yang harus dilakukana agar dapat terhindar dari kepunahan.

\section{METODE}

\section{Koleksi Sampel}

Sampel didapatkan dari Suaka Rhino Sumatera (SRS) yaitu diantaranya (Torgamba berasal dari Riau, dan Andalas yang dilahirkan di Cincinati zoo yang kedua induknya berasal dari Bengkulu), serta sampel lainnya yaitu 2 ekor betina yang bernama Bina dan Rosa. Dalam pengambilan darah dibantu oleh dokter hewan yang bertugas dalam bidang kesehatan dan reproduksi Badak Sumatera di SRS.

\section{Isolasi DNA}

Isolasi DNA berdasarkan pada metode yang diungkapkan oleh Duryadi (2005). Amplifikasi PCR menggunakan penanda genetik yaitu cytochrome oxidase 1 (CO1) dengan menggunakan primer tersebut yaitu 1 (RHCOIF \& RHCOIR) menghasilkan fragmen DNA berukuran $711 \mathrm{bp}$.

Proses amplifikasi cytochrome oxidase 1 (CO1) dilakukan dengan kondisi PCR diawal dengan proses predenaturasi pada suhu $94^{\circ} \mathrm{C}$, dilanjutkan dengan siklus utama, antara lain tahap denaturasi suhu $94^{\circ} \mathrm{C}$ selama 45 detik, dilanjutkan dengan tahap (annealing) penempelan primer suhu $58^{\circ} \mathrm{C}$ selama 45 detik serta berikutnya (extension) polimerasi pada suhu $72^{\circ} \mathrm{C}$ selama 1 menit dengan jumlah siklus 35 kali PCR diakhiri dengan (final exstension) polimerasi pada suhu $72^{0} \mathrm{C}$ selama 1 menit.

PCR dilakukan dalam tabung Eppendorf menggunakan KIT PCR terdiri atas ddH2O = $34.25 \mu \mathrm{l}$, buffer PCR $=5 \mu \mathrm{l}, \mathrm{MgCl} 2=2,5 \mu \mathrm{l}$, $\mathrm{dNTP}$ mix $=1 \mu \mathrm{l}$, sepasang primer $=1 \mu \mathrm{l}$, DNA templete $=2 \mu \mathrm{l}$ Taq DNA polymerase $($ Promega $)=0,25 \mu \mathrm{l}$.

DNA hasil PCR dikonfirmasi kebenarannya dengan menggunakan gel elektroforesis. Kemudian sekuensing DNA dilakukan di First Base company.

Hasil seekuensing dilakukan alignment urutan DNA diedit menggunakan perangkat lunak BioEdit (Hall 1999) kemudian di aligned atau dijajarkan dengan program Clustal X (Larkin et al. 2007) dan didapatkan 
sekuen basa nukleotida kemudian data sekuen dianalisa dengan softwere MEGA versi 7.0. Serta menggunakan data NCBI untuk data diantaranya (Ceratorium simum) (NC001808), (ii) (Diceros bicornis) (NC388287), (iii) (Rhinoceros unicornis) (NC001779). Analisis kekerabatan/ filogeni yaitu memakai MEGA softwere 7.0.
Gen CO1 pada Badak Sumatera menghasilkan fragmen DNA berukuran 711 bp. Sedangkan pada badak India berukuran 1544 pasangan basa (pb). Panjang nukleotida dari CO1 teramplifikasi menggunakan primer spesifik RHCOIF \& RHCOIR. Dengan demikian analisa sekuen yang dilakukan tidak keseluruhan panjang pada gen $\mathrm{CO} 1$ pada Badak Sumatera.

\section{HASIL DAN PEMBAHASAN}

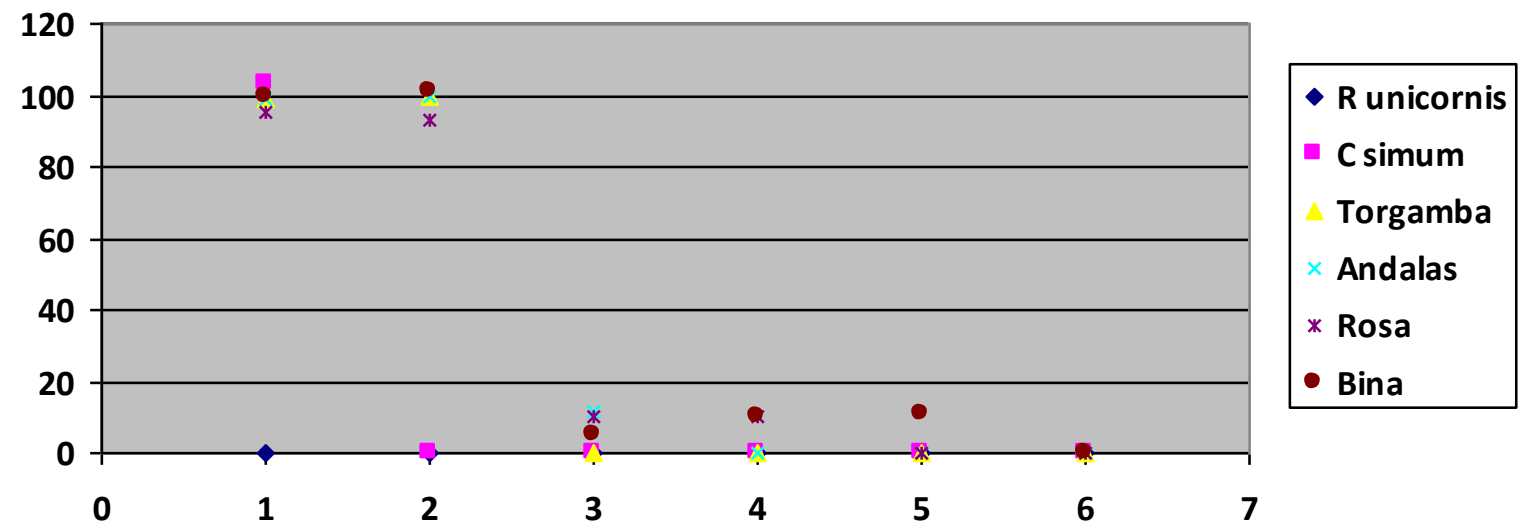

Gambar 1. Variasi basa nukleotida pada Badak Sumatera

Gambar 1 menunjukkan jumlah perbedaan basa nukleotida diantara keempat individu Badak Sumatera dengan badak India berkisar 95 - 100 nukleotida, sedangkan jumlah DNA yang berbeda dengan badak putih Afrika 93 101 nukleotida. Sebaliknya, jumlah perbedaan nukleotida antara Badak Sumatera berkisar 5 11 basa. Betina bernama Rosa (†) memiliki perbedaaan nukleotida 10 basa dengan jantan bernama Torgamba $(\hat{O})$, dan dengan Andalas (ठ) memiliki perbedaan 10 nukleotida. Antara Rosa (q) dengan Bina ( + ) terdapat perbedaan 11 nukleotida, sedangkan antara Torgamba (ठ) dengan Andalas (ठ) berbeda 10 nukleotida. Sementara itu, perbedaan jumlah nukleotida antara Torgamba $(\widehat{O})$ dengan Bina $($ ) relatif kecil yaitu hanya 5 nukleotida.

\section{Hubungan Kekerabatan Badak Sumatera Berdasarkan Sekuen CO1}

Terlihat pada hasil sekuen gen CO1 didapatkan sebesar 711 bp. Hasil analisis genetik menunjukkan bahwa empat individu badak sumatera yang diteliti terpisah dengan badak yang berasal dari Afrika. Adanya perbedaan pada badak di dunia dapat dilihat dari hasil analisa variasi genetik seperti yang telah dilakukan dalam penelitian ini, bukan melihat dari jumlah cula yang ada pada badak, karena berdasarkan morfologi terdapat perbedaan yang jelas antara badak India, badak Jawa, Badak Sumatera dan badak Afrika. 
Konservasi Hayati, 17 (1): 44-48, April (2021)

https://ejournal.unib.ac.id/index.php/hayati/

p-ISSN: 0216-9487

email:konservasihayati@unib.ac.id

e-ISSN: 2722-1113

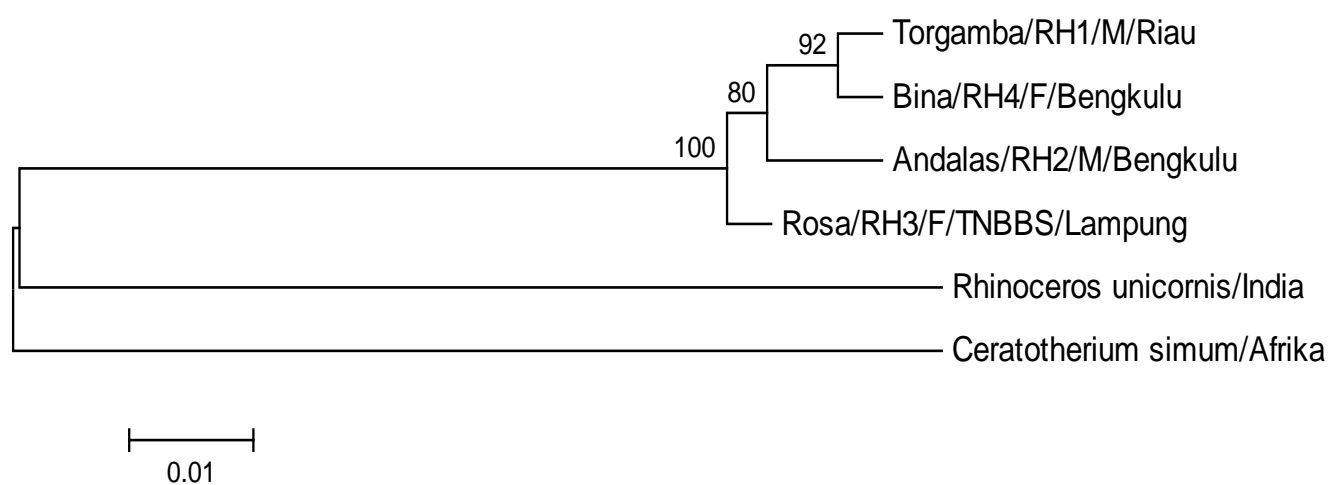

Gambar 2. Dendogram Neighbor-Joining dengan pengolahan bootstrap 1000 ulangan dari nukleotida gen CO1

Hasil sekuen gen CO1 menunjukkan bahwa badak jawa, badak India, badak Badak Sumatera didapatkan dalam satu pengelompokkan (kluster). Terlihat bahwa Badak Sumatera yang memiliki jumlah cula dua terpisah dari badak Afrika yang juga memiliki jumlah cula yang sama yaitu bercula dua. Sehingga, pengelompokan dan penamaan genus berdasarkan jumlah cula tidak tepat lagi. Penamaan yang tepat dapat dilakukan berdasarkan data genetik dan molekulernya. Penamaan genus pada badak Afrika tidak didasarkan jumlah cula, namun dilakukan berdasarkan warna kulit yaitu berkulit hitam (Diceros) dan berkulit putih (Ceratotherium).

Berdasarkan hasil yang diperoleh, Badak Sumatera berbeda secara genetik dengan badak Afrika, meskipun sama-sama memiliki dua cula. Berdasar hasil sekuen, Badak Sumatera secara genetik lebih dekat kekerabatannya dengan badak Jawa dan badak India yang memiliki satu cula. Adanya perbedaan jumlah cula tidak mempengaruhi hubungan kekerabatan. Namun kedekatan kekerabatannya lebih didasarkan pada sebaran geografis. Terjadi perbedaan diantara badak tersebut terjadi karena adanya pemisahan secara geografis.

\section{PENUTUP}

Gen CO1 dapat digunakan sebagai penanda genetik badak berdasarkan sekuen basa nukleotida sehingga dapat membedakan spesies badak. Dari data gen CO1. Badak
Sumatera terpisah dari badak Afrika. Sehingga diperlukan adanya penelitian lanjutan, khususnya Badak Sumatera dengan penambahan spesies dan jumlah sampel tiap spesies. Hasil pengujian diharapkan dapat memberikan hasil yang baik dan akuratif untuk seluruh spesies badak di Indonesia.

\section{DAFTAR PUSTAKA}

Alikodra, H.S. 2002. Pengelolaan Satwa Liar Jilid I. Departemen Pendidikan dan Kebudayaan Direktorat Pendidikan Tinggi Pusat Antar Universitas IPB. Bogor.

Avise, J.C. 2004. Molecular Markers, Natural History, and Evolution. Sinauer Assocoates, Sunderland, M.A.

Duryadi, D. 1994. Peran DNA Mitokondria (mtDNA) dalam Studi Keragaaman Genetik dan Biologi Populasi pada Hewan. Jurnal Hayati 1(1): 1-4.

Duryadi, D. 1997. Isolasi dan Purifikasi Mitochondria (mtDNA). Laboratorium Biologi Molekuler Pusat Penelitian Sumberdaya Hayati dan Bioteknologi (PPSH) IPB. Institut Pertanian Bogor. Bogor.

Fernano, P., Polet, G. Foead, N., Linda. 2006. Genetic Diversity, Phylogeny and Conservation of the Java rhinoceros (Rhinoceros sondaicus). Journal Conservation Genetics. 7 : 439-448.

Frankham, R.J.D. 2002. Introduction to Conservation Genetics. Cambridge 
Konservasi Hayati, 17 (1): 44-48, April (2021)

https://ejournal.unib.ac.id/index.php/hayati/

p-ISSN: 0216-9487 email:konservasihayati@unib.ac.id

Univeristy Press. Cambridge.

Groves, C.P. 1983. Phylogeny of the Living Species of Rhinoceros. Z.Zool.Syst.Evolutionsforsch. $21: 293$ 313.

Hubback. 1939. The Asiatic Two-Horned Rhinoceros. Journal of Mammology. 20 (1) : 1-20.

IUCN. 1996. The IUCN Red List of Threatened Animal. IUCN Gland. Switzerland.

Kumar, S., Tamura, K., Dudley, J., Nei, M. 2007. MEGA4: Molecular Evolutionary Genetics Analysis (MEGA) software version 4.0. $\mathrm{J} \mathrm{Mol}$ Biol Evol. 24 (8): 1596-1599.

Lekagul B., McNelly. 1977. Mammals of Thailand. Sahakarnbhat Co. Bangkok.

Nowak, R.M. 1991. Walker's mammals of the world. University Pers. Baltimore \& London.

Penny, M. 1987. Rhino Endangered Spesies. Christopher Helm London. London.

Primack. 1998. Biologi Konservasi. Yayasan Obor. Indonesia

Van Strien, N.J. 1985. The Sumatran Rhinocerus Dicerorhinus sumatrensis (Fiscer, 1814) in The Gunung Leuser National Park, Sumatera, Indonesia, Its Distribution, Ekology and Conservation. Privately Publisher.

WWF. 2002. Asian Rhinos- Spesies Status Report. WWF.

Yayasan Mitra Rhino. 1998. Program Konservasi Badak Sumatera. Laporan Tahunan Bidang Survey dan Patroli Rhino Protection Unit (RPU) Taman Nasional Way Kambas periode Desember 1996 - Desember 1998. 